\title{
Sicilian Lemon and Honey Light Fermented Milk
}

\author{
Lenita Kuster de Albuquerque ${ }^{1}$, Valéria da Silva Alves ${ }^{2}$, Marcus Vinicius Martins Taveira ${ }^{3}$ and Denise de \\ Mello Bobany ${ }^{2 *}$
}

${ }^{1}$ Graduated in Veterinary Medicine from the University Center Serra dos Órgãos - UNIFESO, Brazil

${ }^{2}$ Professor of Veterinary Medicine of University Center Serra dos Órgãos - UNIFESO, Brazil

${ }^{3}$ Biologist and Laboratory Technician of University Center Serra dos Órgãos - UNIFESO, Brazil

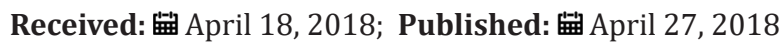

*Corresponding author: Denise de Mello Bobany, Professor of Veterinary Medicine of University Center Serra dos Órgãos - UNIFESO, Brazil

\begin{abstract}
The development of products enriched with physiological components such as probiotics and prebiotics has been a top priority in the food industry research. Fermented milk have a fundamental character in eating habits, since they represent an important source of calcium and may present a variety of nutritional characteristics indispensable to well-being. This reality conditions the needs of the market, which leads to the investigation and creation of new flavors, new textures, among others, according to the different target audiences. The present work had as objective the production and the accomplishment of a sensorial analysis of the light fermented milk of Sicilian lemon and honey through the Test of acceptance and intention of purchase. The acceptance test and purchase intention confirmed the feasibility of production of this project.
\end{abstract}

Keywords: Dairy product; New products; Sensory analysis

\section{Introduction}

The lifestyle that modern man is compromised by the consumption of inadequate food, tobacco use, alcohol, daily stress and sedentary lifestyle, making diseases that have a major impact on health such as hypertension, cardiac risk, degenerative diseases and gastrointestinal diseases, modern pathologies increasingly common. The development of foods that promote health and wellbeing is one of the key priorities of research in the food industry and has favored the consumption of light foods enriched with physiologically active components such as probiotics and prebiotics $[1,2]$. Probiotics are defined as a single or mixed culture of living microorganisms, which benefit humans or animals by improving the properties of the intestinal microbiota [1].

Prebiotics are non-digestible food components that beneficially affect the host by selectively stimulating the proliferation or activity of desirable bacteria populations in the colon. In addition, the prebiotic such as honey, can inhibit the multiplication of pathogens, guaranteeing additional benefits to the health of the host [3]. Fermented milk have a prominent relevance in eating habits, since they represent an important source of calcium, and also because they have varied nutritional characteristics indispensable for wellbeing. It will then be found that it is an essential product in the daily life of each one of us. This reality conditions the needs of the market, which leads to the investigation and creation of new flavors, new textures, among others, according to the different target audiences [4]. The objective of this project was the formulation of a light sicilian lemon and honey fermented milk, added with prebiotics and probiotics, that meets the expectations and objectives of a functional food.

\section{Material and Methods}

The present work followed the flowchart indicated by Witschinski [5], and its methodology was divided into two parts. The first consisted of the elaboration of a light fermented milk of Sicilian lemon and honey, which presented a creamy texture and reduced action of syneresis. The second part of the work consisted of the elaboration of the sensorial analysis of light fermented milk of Sicilian lemon and honey, with affective tests of acceptance and test intention of purchase. 


\section{Product development}

The fermented light sicilian lemon milk with honey was elaborated in the laboratory of products of animal origin (POA), at the Quinta do Paraíso campus, of University Center Serra dos Orgãos -Teresópolis-Rio de Janeiro - Brazil. The following were used: 3 liters of skim milk; Culture of Lactobacillus acidophilus LA5, Bifidobacterium BB-12 and Streptococcus thermophilus; Light milk cream; Sicilian lemon juice; Wild honey (APIÁRIO SERRANO); Aspartame; Thick gelatin. The milk was heated to $42{ }^{\circ} \mathrm{C}$ and then inoculated with the mesophilic culture and added with thickener. In order to improve the texture of the product and decrease the syneresis, making it more creamy, the gelatin thickener was used. This mixture was homogenized slowly until the thickener was dissolved and then placed in an oven at $42{ }^{\circ} \mathrm{C}$ for 4 hours. At this moment the milk fermentation occurred and the milk coagulated. The $\mathrm{pH}$ was measured at 5.0. After the oven time, the milk was cooled to $10^{\circ} \mathrm{C}$.

A syrup was made with sicilian lemon juice, honey and aspartame. This syrup was heated to $80{ }^{\circ} \mathrm{C}$ for 30 minutes, being reduced and cooled to $10^{\circ} \mathrm{C}$. This syrup was mixed slowly with the fermented milk and being added with milk cream. The mixture was homogenized to avoid lumps. The container was filled into disposable plastic cups of $50 \mathrm{ml}$, and conditioned at a cooling temperature of $4{ }^{\circ} \mathrm{C}$, to carry out the sensory analysis in the next 16 hours. After 12 hours of cooling the $\mathrm{pH}$ obtained was 4.5. Sensorial analysis: Sensorial analysis was carried out on May 6, 2016, at the Food Laboratory of the University Center Serra dos Órgãos Teresópolis - Rio of January - Brazil, applying the Affective Sensory Method through the acceptance test and purchase intention test. A total of 110 untrained tasters participated in the sensory analysis, at random. Individual benches were available for each taster composed of product sample, a glass of water and a questionnaire.

\section{Results and Discussion}

After preliminary tests, a satisfactory formulation was reached in relation to the texture, creaminess and acidity requirements. The use of the cream in the elaboration of the fermented milk helped to provide the desired creaminess. According to Golçaves and Eberle [1], the addition of cream can make the final product present some buttery flavor. This phenomenon was not observed in the final product because it was in lower concentrations of cream following the proposal of light food. In the texture attribute, it was found that the use of thickener aided in the absence of syneresis avoiding desorption of the product according to Costa et al. [2]. The fermented milk produced presented a creamy texture, smooth and with slight cut resistance.

In terms of taste and acidity, it was verified that the sicilian lemon syrup and honey had the desired acidity. The sweet taste of honey inhibited the excessive acidity of the Sicilian lemon. These results are in agreement with Macedo et al. [3], who says that the acidity of the lemon is inhibited by the addition of honey. Of the 110 testers, 63 (51.81\%) were women, and 47 (48.19\%), men, aged 20-60 years. The test results show that $50 \%$ of the tasters liked the product a lot. $32.72 \%$ liked extremely; $11.81 \%$ of the tasters liked moderately; $2.72 \%$ of the tasters liked it slightly; $1.81 \%$ of the testers were indifferent about the product, and only $0.9 \%$ of the testers reflected mild to indifferent dislike of the product.

In the test of purchase intention, of the 110 testers, $51.81 \%$ answered that they would definitely buy; $40.90 \%$ would likely buy; $4.54 \%$ answered yes, maybe they would not buy, and only $2.72 \%$ would not buy the product. The sensorial analysis demonstrated that the product had an acceptance of $97.25 \%$ against only $2.71 \%$ of rejection. In the analysis of intention to buy, of the 110 testers, $92.72 \%$, having liked it extremely or only liked, decided to buy the product.

\section{Conclusion}

The light fermented milk of Sicilian lemon and honey proved to be a product of great acceptance by the possible consumer market.

\section{References}

1. Golçaves A, Eberle I (2008) Frozen Yogurt com bactérias probióticas. Alim. Nutr. Araquara 19(3): 291-297.

2. Costa AVS, Nicolau ES, Torres MCL, Fernandes PR, Rosa SIR, et al. (2013) Desenvolvimento e caracterização físico-química, microbiológica e sensorial de bebida láctea fermentada elaborada com diferentes estabilizantes/espessantes. Semina: Ciências Agrárias Londrina 34(1): 209-226.

3. Macedo IN, Luchese RH, Guerra AF, Barbosa CG (2008) Efeito prebiótico do mel sobre o crescimento e viabilidade de Bifidobacterium spp. e Lactobacillus spp. em leite. Ciência e Tecnologia de Alimentos 28(4): 935-942.

4. Malajovich MAA (2016) Fermentação láctica (1). Rio de Janeiro Biotecnologia ensino e divulgação. p4.

5. Witschinski F (2012) Elaboração de iogurte com adição de frutooligossacarídeo e cultura probiótica (Bifidobacterium) 105f. Dissertação (Mestrado) - Universidade Regional Integrada do Alto Uruguai.

6. Lunardello Kamila Avelino (2009) Influência do uso combinado de hidrocolóides nas características do iogurte natural desnatado dissertação (Mestrado em Ciência e Tecnologia do Leite) - Universidade Norte do Paraná, Londrina. 
This work is licensed under Creative Commons Attribution 4.0 License

Submission Link:

Submit Article

DOI: $10.32474 /$ CDVS.2018.01.000107

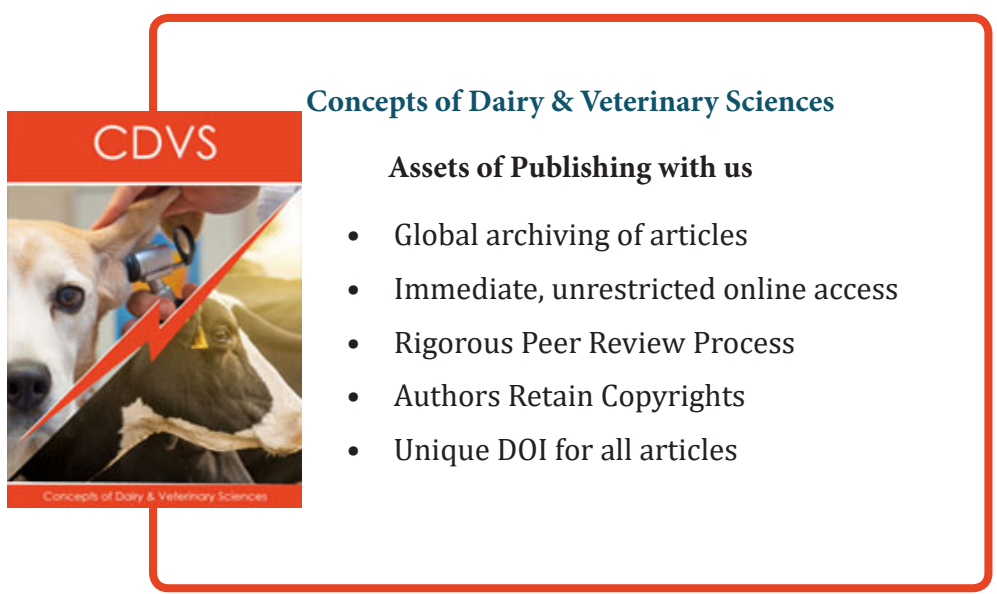

